\title{
The Impact of Foreign Tourists Visit Growth Toward Accomodation and Macroeconomic Aspects in Indonesia Over The Period 2000-2016
}

\author{
Farida Elmi, Rosalendro Eddy Nugroho
}

\begin{abstract}
The long-term objective of the study is to create a professional landscape model of labor / HR professionals in the tourism industry and recommend a professional HR policy in the archipelago tourism industry business in Sumatera through continuous competitive foreign tour visits from aspects of accommodation, hotel rooms, beds, air, air routes and increasing the welfare rate of island communities in Sumatra in particular and the growth of the national economy in general. The purpose of this research is to analyze the influence of the ratio of accommodation, airplane ratio, air route ratio, hotel room ratio, beds ratio, human resources / tourism workforce and economic growth rate in Sumatra Island to the ratio of foreign tourist visit over the period 2000-2016. The type of quantitative research with causal method, to be more representative sampling technique is conducted with purposive sampling, with multiple linear regression data analysis. Stages of research study of literature and secondary data, research result is model and policy recommendation for tourism industry and projection of economic growth of archipelago in Sumatera and national in general for 2018-2025 seen from some tourism sector. The research output is in the form of a model, policy recommendation and blueprint for tourism services of Sumatera Island, tourism agencies of the region and The Ministry of Tourism.
\end{abstract}

Index Terms - Accommodations, Aircraft Ratios, Air Routes, Hotel Rooms, Hotel Beds, HR and Growth Rate of the Economy.

\section{INTRODUCTION}

Currently, tourism or tourism activities are increasingly playing an important role in the global economy. In fact, for more than half a century, tourism has been a source of global economic growth and employment. This is because tourism is now the world's largest industry and one of the fastest growing sectors by reaching more than a third of the total value of world services trade and contributing trillions of dollars annually to the global economy (Meihami and Karami, 2014).

In fact, the tourism development is able to promote and accelerate the national economic growth by creating the demand of both consumption and investment, which in turn will trigger the production of goods and services. In tourism activities, tourists will conduct shopping and travelling consumption, thus immediately creating market demand for

Farida Elmi ' Master of Management Program, Universitas Mercubuana Jakarta, Indonesia

Rosalendro Eddy Nugroho, Master of Management Program, Universitas Mercubuana, Jakarta, Indonesia goods and services. Furthermore, the demand in tourism activities also indirectly increases the demand for capital goods and raw materials to produce goods and services required by the tourists (Santi et al, 2013).

From Table 1 (2009-2014), based on data from the Central Bureau of Statistics (BPS), there has been an increase of approximately 49.3 percent in the last ten years to as many as 9.43 million foreign tourists in 2014 or an average of about 9.84 percent per year. In 2015, cumulatively (January-July) 2015 , the number of visits by foreign tourists reached 5.47 million visits or an increase of 2.69 percent compared to the previous year's visit 5.33 million.

The table 2 also shows that the increase in the number of tourist visits is also followed by an increase in the amount of expenditure or foreign tourists' consumption of 18.89 percent during the period 2009-2014 which amounted to 1.183 US dollars. In addition, according to data from the Ministry of Tourism and Creative Economy, the tourism industry is able to provide employment of approximately 192.210 million people or 8.46 percent of total employment available in 2012. Table. 1. Touris Growth from Arround the World come to Indonesia 2009-2014 . Source: BPS (2017)

\begin{tabular}{|c|r|l|l|}
\hline \multicolumn{1}{|c|}{ Year } & Asia Pacific & \multicolumn{1}{l|}{ USA } & Europe \\
\hline 2009 & 4917083 & 237670 & 1028405 \\
2010 & 5527342 & 255465 & 1048543 \\
2011 & 6050406 & 293306 & 1110871 \\
2012 & 6376166 & 312525 & 1174079 \\
2013 & 6943413 & 343573 & 1285097 \\
2014 & 7475049 & 361220 & 1337553 \\
\hline
\end{tabular}

Table. 2. Touris Growth from Arround the World come to Indonesia 2009-2014. Source: BPS (2017)

\begin{tabular}{|c|c|c|}
\hline Year & $\begin{array}{c}\text { Midle East } \\
\text { Africa }\end{array}$ & $\begin{array}{c}\text { Average Spending } \\
(\text { \$ })\end{array}$ \\
\hline 2009 & $\mathbf{1 4 0 5 7 2}$ & $\mathbf{2 3 7 ~ 6 7 0}$ \\
2010 & $\mathbf{1 7 1 5 9 4}$ & $\mathbf{2 5 5 4 6 5}$ \\
2011 & $\mathbf{1 9 5 1 4 8}$ & $\mathbf{2 9 3 3 0 6}$ \\
2012 & $\mathbf{1 8 1 6 9 2}$ & $\mathbf{3 1 2 5 2 5}$ \\
2013 & $\mathbf{2 3 0 0 4 6}$ & $\mathbf{3 4 3 5 7 3}$ \\
2014 & $\mathbf{2 6 1 5 8 9}$ & $\mathbf{3 6 1 2 2 0}$ \\
\hline
\end{tabular}




\section{LITERATUR REVIEW}

Tourism according to Meihami and Karami (2014) can be defined as a voyage between the region of origin and destination with the motivation for temporary reside, recreation, trade, culture and entertainment. Cultural tourism (cultural tourism) is the most familiar form for tourists. Whilst according to the World Tourism Organization, tourism is a travel activity of one who travels to and stays somewhere outside his or her daily setting within a period of no more than a year for leisure, business, etc. Pendit in Baruddin (2011) states that tourism consists of activities such as cultural, health, culinary, educational, religious, business, industrial, convention, political, social, pilgrim tours, honeymoon, nature reserve, research, marine, and adventure tours..

In his dissertation Santi Singagerda (2014) declared that in its activities, tourism can be viewed from two senses, namely supply and demand. Both sides are the scope of tourism economic activities that interplay each other. Tourism viewed from the supply side is a business that provides goods or services for the fulfillment of the needs of tourism activities and tourism operation.

While tourism from the demand sense based on the recommendation of World Tourism Organization by United Nations Statistical Commission in 1993 (UNWTO Tourism Highlights, 2009) it is acknowledged that tourism consists of three types, namely: (1) domestic tourism, which is a resident of a country traveling within the state territory (2) inbound tourism, i.e. the foreign residents who travel to a country. (3) outbound tourism, i.e. residents who travel abroad. The three types of activities will eventually create a demand for tourism services, and the need for goods / services to be consumed during the trip.

\section{A. Formulation of The Problem}

The rapid growth of Tourism Industry is a fantastic economic phenomenon along with the increasing of infrastructure development in Indonesia, as a result, induce on foreign travelers' visit. The number of foreign tourist in Indonesia is influenced by various things including accommodation, aircraft, air route, tourism labor, hotel room, bed, and national economic growth. On the basis of the above problems, the research questions to be addressed in this study are:

1).How is the influence of accommodation, aircraft, air route, tourism labor, hotel room, bed, and national economic growth toward foreign tourist visits in Indonesia over the period 2000 - 2016?

2).Which factors are most influential on Indonesia' Foreign Tourist Visits to accommodation, aircraft, air route, tourism labor, hotel room, bed, and national economic growth over the period 2000-2016?

\section{B. Research Purposes}

Based on the background and formulation of the above problems, the objectives to be achieved in this research are:

1). Analizing the influence of accommodation, aircraft, air route, tourism labor, hotel room, bed, and national economic growth toward foreign tourist visits in Indonesia from 2000 -
2016 ?

2). Analizing which factors have the most influential on Indonesia's foreign tourist visits to accommodation, aircraft, air route, tourism labor, hotel room, bed, and national economic growth over the period 2000-2016?

\section{METHOD}

Methods of causal research aimed at examining the effect of foreign tourist visits in Indonesia over the period 2000 2016 on accommodation, aircraft, air route, tourism labor, hotel room, bed, and national economic growth. The technique used to obtain a representative sample is purposive sampling. The data used in this study is secondary data. Secondary data obtained from Central Bureau of Statistics, Bank of Indonesia and KOMPAS newspaper.

The method of analysis in this study using multiple regression analysis method and the deviation test against the classical assumption which includes multicolinearity test, autocoleration test, and heterokedastisity test.

In analyzing the factors influencing foreign tourist visits in Indonesia in period 2000-2016, the model used:

$$
\begin{aligned}
& \mathrm{LgY}=\alpha+\beta 1 \mathrm{LgPDB}+\beta 2 \mathrm{LgSDM}+\beta 3 \mathrm{LgKH}+\beta 4 \mathrm{LgAK}+ \\
& \beta 5 \mathrm{LgTT}+\beta 6 \mathrm{LgPT}+\beta 7 \mathrm{LgRU}
\end{aligned}
$$$$
\text { Where: }
$$

$\mathbf{Y}=$ Foreign Tourist Ratios

PDB = National Economic Growth in Indonesia

TT $=$ Number of Beds

AK = Accomodation of Services

SDM $=$ Tourism Works

$\mathbf{K H}=$ Number of Hotel Rooms

PT $=$ Number of Aircrafts

RU $=$ Number of Air Routes

$\boldsymbol{\alpha}=$ Constants

$\mathbf{L g}=$ Logarithmic Function

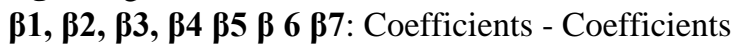
National Economic Growth, Beds, Number of Aircraft, Accommodation Service, Number of Hotel Rooms, Number of Air Routes and Workforce of the Tourism Sector in Indonesia 2000 - 2016 are the independent variables which partially or jointly assumed to affect foreign tourist.

\section{RESUlt AND DisCUSSION}

\section{A. Simultaneous Test $(F)$ [Conformity Model]}

Based on the ANOVA or F test table, the calculated F count is 529,100 with probability rate of 0.000 . Since probability is less than 0.05 , it can be concluded that the regression coefficient of Accommodation (AK), Aircraft (PT), Air Route (RU), Tourism Labor (SDM), Hotel Room (KH), Beds (TT ) and the National Economic Growth (PDB) or the seven independent variables simultaneously affect the foreign tourist visit in Indonesia over the period 2000-2016. This also means the value of determination coefficient of $\mathrm{R}^{2}$ is not equal to zero or significant. Details can be seen in Table 1.0 below: 
Table 3 Simultaniuos Test (ANOVA)

\begin{tabular}{|c|c|c|}
\hline \multirow{2}{*}{ Model } & $\mathbf{F}$ & Sig. \\
\cline { 2 - 3 } & $\mathbf{5 2 9 , 1 0}$ & $\mathbf{0 , 0 0 0}^{\mathbf{a}}$ \\
\hline
\end{tabular}

a. Predictors: (Constant),SDM,TT,KH,AK,PT,RU

b. Dependent Variable: Y

Source: Processed data (2018)

\section{B. Coefficient of Determination}

The external outer view of the SPSS model summary shows the magnitude of Square $R^{2}$ of 0.998 . This means that the foreign tourist visits in Indonesia in the period of 2000 2016 is $99.8 \%$ can be explained by the variation of the seven independent variables i.e. Accommodation (AK), Aircraft (PT), Air Route (RU), Tourism Labor (HR), Hotel Room (KH), Bed (TT) and National Economic Growth (GDP).

Whilst the rest $(100 \%-99.8 \%=0.2 \%)$ is explained by other causes outside the model, Standard Error of Estimate [SEE] of 0.0137, the smaller the value of SEE the more precise for the regression model to predict the dependent variables, for more details can be seen in Table 4.0 below:

Table 4 Coeficient of Determination

\begin{tabular}{|c|c|r|r|}
\hline \multirow{4}{*}{ Model } & R & R Square & Durbin-Watson \\
\cline { 2 - 4 } & $\mathbf{0 , 9 9 9}^{\mathbf{a}}$ & $\mathbf{0 , 9 9 8}$ & $\mathbf{2 , 0 2 3}$ \\
\hline
\end{tabular}

a. Predictors: (Constant), SDM,TT,KH,AK,PT,RU

b. Dependent Variable:Y

Source: Processed data (2018).

\section{Multiple Regression Equations}

To interpret the coefficients parameters of independent variables can use unstandardized coefficients and standardized coefficients. The seven independent variables included in the model apparently only five (5) variables [Accommodation (AK), Aircraft (PT), Air Routes (RU), Hotel Rooms (KH), Beds (TT) are significant at $\alpha<5 \%$, it can be seen from the significance probability of both is far below $0.05[\mathrm{RU}=0.019<0.05 ; \mathrm{KH}=0.006<0.05 ; \mathrm{TT}=0.001$ $<0.05 ; \mathrm{AK}=0,007<0,05 ; \mathrm{PT}=0,001<0,05]$ and only two (2) independent variable that influenced insignificantly that is Tourism Labor (SDM) and National Economic Growth (GDP) because $\alpha>5 \%$, where SDM $=0.930>0.05$ and GDP $=0.371>0.05$. For more detail see Table 3 below:
Table 5 Partial Significance Test (t test).

\begin{tabular}{|c|c|c|c|c|c|}
\hline \multirow[t]{2}{*}{ Model } & $\begin{array}{c}\text { Unstandardized } \\
\text { Coefficients }\end{array}$ & & & Level & Sign \\
\hline & B & $t$ & Sig. & $\begin{array}{c}\alpha<=5 \\
\%\end{array}$ & no \\
\hline (Constant) & 4,848 & 5,892 & 0,000 & $<5 \%$ & Significant \\
\hline RU & 0,033 & 2,858 & 0,019 & $<5 \%$ & Significant \\
\hline KH & $-0,021$ & $-3,550$ & 0,006 & $<5 \%$ & Significant \\
\hline TT & $-0,165$ & $-4,611$ & 0,001 & $<5 \%$ & Significant \\
\hline SDM & $-0,018$ & $-0,017$ & 0,930 & $>5 \%$ & \\
\hline PDB & 0,078 & 0,942 & 0,371 & $>5 \%$ & no \\
\hline AK & $-0,0165$ & $-3,463$ & 0,007 & $<5 \%$ & Significant \\
\hline PT & 1,308 & 5,146 & 0,001 & $<5 \%$ & Significant \\
\hline
\end{tabular}

Depedend Variabel : $Y$

Source: processed data (2018)

1. The constant The coefficient of constant is positive and significant, it states that by assuming the absence of Accommodation (AK), Aircraft (PT), Air Route (RU), Tourism Labor (HR), Hotel Room $(\mathrm{KH})$, Bed (TT) and National Economic Growth (GDP), Foreign tourist visits in Indonesia over the period 2000-2016 has increased by 4,848 units.

2. The regression coefficient of air routes volume (RU) is positive and significant, it states that by assuming the absence of other independent variables, if the number of air routes (RU) increases, the foreign visitor in Indonesia from 2000-2016 increases 0.033 units.

3. The regression coefficient of hotel rooms volume $(\mathrm{KH})$ is negative and significant, it confirms that by assuming the absence of other independent variables, if the number of hotel rooms $(\mathrm{KH})$ increases, the foreign visitor in Indonesia over the period 2000-2016 decreases 0.021 Units.

4. The regression coefficient of number of beds (TT) is negative and significant, it confirms that by assuming the absence of other independent variables, if the number of beds (TT) increases, the foreign visitor in Indonesia over the period 2000-2016 decreases 0.165 Units.

5. The regression coefficient of Tourism Workforce (SDM) is negative and insignificant, it confirms that by assuming the absence of other independent variables, if the Tourism Workforce (SDM) increases then the foreign tourists in Indonesia over the period 2000-2016 decreases 0.018 Units.

6. The regression coefficient of National Economic Growth (GDP) is positive and insignificant it confirms that by assuming the absence of other independent variables, if the National Economic Growth (GDP) increases, then foreign tourists in Indonesia over the period 2000-2016 have increased 0.078 Units.

7. The regression coefficient of Accommodations volume (AK) is negative and significant, it confirms that by assuming the absence of other independent 
variables, if the Number of Accommodations (AK) has increased, the Foreign Visitor in Indonesia over the period 2000-2016 decreased 0.0165 Unit.

8. The regression coefficient Number of Beds (TT) is positive and significant influences, it confirms that by assuming the absence of other independent variables, if the number of beds (TT) increases, the overseas tourists in Indonesia over the period 2000-2016 increases 1.308 Unit.

It can be assumed that foreign tourists in Indonesia in the period of 2000-2016 is affected by Accommodation (AK), Aircraft (PT), Air Route (RU), Tourism Labor (SDM), Hotel Room (KH), and Beds (TT), thus the multiple regression equation can be seen as follows:

\section{Log Y =4,848+0,033LogRU-0,021LogKH-0,165LogTT $-0,0165 \log \mathrm{AK}+1,308 \log \mathrm{PT}$

\section{Test Multicolinearity}

Multicollinearity test aims to test whether in the regression model found a high or perfect correlation between independent variables. If the inter-independent variable is a perfect multicolinearity, then the independent variable regression coefficient cannot be determined and the standard error value becomes infinite. If the multicollinearity between independent variables is high, then the regression coefficient of independent variables can be determined but has a high standard error value means the regression coefficient value. Cannot be estimated properly.

a). Table 4.0 shows that RU and $\mathrm{KH}$ have $\mathrm{CI}$ values between 10 - 30 which means there is light multicolinearity. Then other variables have CI values above 30 indicating strong multicollinearity that is AK, KH, SDM, PDM and PT..

b). Based on table 4.0, it is evident that RU, AK, KH, TT and GDP have tolerance values above 0.10 . It can be concluded that there is no multicollinearity, whereas for Tolerance below 0.10 ie HR (0.008) \& PT (0.008). It can be concluded that there is mild multicolinearity. As for the VIF; Independent Variables; RU, AK, KH, TT and GDP which are below 10 therefore VIF with Independent Variables; RU, AK, $\mathrm{KH}$, TT and GDP, can be inferred that there is no multicolinearity. While for VIF above 10 that is HR $(125,192)$ \& PT $(130,808)$.

Tabel 6 Tolerance, VIF dan CI Independen Variabel

\begin{tabular}{|c|c|c|c|}
\hline \multirow{2}{*}{ Model } & \multicolumn{2}{|c|}{ Collinearity Statistics } & \multirow{2}{*}{ CI } \\
\cline { 2 - 3 } & Tolerance & VIF & \\
\hline (Constant) & & & 1 \\
RU & 0,264 & 3,783 & 12,357 \\
KH & 0,659 & 1,518 & 20,852 \\
TT & 0,317 & 3,15 & 49,687 \\
SDM & 0,008 & 125,192 & 89,907 \\
PDB & 0,371 & 0,249 & 158,642 \\
AK & 0,297 & 3,363 & 232,114 \\
PT & 0,008 & 130,808 & 1480,02 \\
\hline
\end{tabular}

Source (2018)

\section{E. Autocorrelation Test}

Autocorrelation test aims to test whether in a linear regression has a correlation between residual errors in period $t$ with error in period $\mathrm{t}-1$ (previous). If there is a correlation, then there is an autocorrelation problem. Autocorrelation arises because of sequential observations over time related to each other (Janie, 2012). This problem arises because residuals are not free from one observation to another. This is often found in time series data because the disruption in a person / individual / group tends to affect the disruption of the same individual / group in then next period.

There are several ways that can be used to detect the presence or absence of autocorrelation. One common way of detecting autocorrelation in multiple linear regression is with Durbin Watson (DW) Test. D-W test is one of the most widely used test to determine whether or not there is autocorrelation. Almost all statistical programs already provide facilities to calculate the value of $d$ (which describes the DW coefficients). The $d$ value will be in the range of 0 to 4 , see the following table: : A-5a (Gujarati, 2010) $\rightarrow$

$\mathrm{n}=17 \& \mathrm{k}=7$ obtained $\mathrm{dL}=0.451 ; \mathrm{dU}=2,537$

\section{4-dU $<d<4-d L \rightarrow 4-2,537<2,023>4-0,451 \rightarrow 1,463<2,023$} $<3,549$

Based on the test results in Table 4.8. the equation of Multiple Regression Analysis the value of Durbin Watson (DW) obtained is $=2,023$. It means $d$ is between 1.463 and 3.549 then the conclusion of foreign tourists in Indonesia in the period 2000 - 2016 that no decision or dubious $\rightarrow$ Ho; areas means no autocorrelation.

\section{F. Test Heteroscedasticity}

There are two ways of detecting the presence or absence of Heteroskedasticity, namely by the method of graphs and statistical methods. Graph method is usually done by looking at the plot graph between the predicted values of the dependent variable with the residual. While statistical methods can be used to identify the presence of Heteroskidasticity problems, some of these methods are Park Test, Glejser Test, Spearman Test, Goldfeld-Quandt Test, Bruesch-Pagan-Godfrey Test and White Test. But that will be discussed in this section only Graphs and Glejser Test methods.

Glejser Test. The results can be observed in table 6.0. it clearly shows the entire variables, Accommodation (AK), Aircraft (PT), Air Route (RU), Tourism Labor (HR), Hotel Room (KH), Bed (TT) and National Economic Growth (GDP) all of which show significance values above 0.01 . This means there is no Heteroscedasticity in this model, in other words all independent variables mentioned in this model have the same or homogeneous variant.

Table. 7. Glejser Test Table which No Heteroscedastisity.

\begin{tabular}{|c|c|}
\hline Model & Sig \\
\hline Constant & 0,348 \\
RU & 0,177 \\
KH & 0,461 \\
TT & 0,915 \\
SDM & 0,314 \\
PDB & 0,766 \\
AK & 0,911 \\
PT & 0,286 \\
\hline
\end{tabular}

Dependent Variable :AbsUi

Source:Processed Data(2018) 


\section{CONCLUSION}

Number of Accommodations (AK), Aircraft (PT), Air Routes (RU), Hotel Rooms(KH) and Beds (TT), Human Resources (SDM), and National Economic Growth (GDP) influence significantly to the number of foreign tourist visits in Indonesia over the period 2000-2016.

The number of Air Routes (RU) and Aircraft (PT) contributes positively and significantly, while the Number of Accommodations (AK), Hotel Rooms (KH) and Beds (TT) contributes negatively and significantly to the Number of foreign tourist Visits in Indonesia over the period 2000-2016.

The nature and tourism potential that has become the lifestyle of today's society can be the basis for economic growth through tourism development, exploring the archipelagic natural potentials in Sumatra can be tailored in a tour package to provide significant opportunities and development, this is a milestone as the main capital for the Central Government and the local administration should be in line with the local community to identify potential tourism markets, design a plan, improve accommodation such as initiating a growth oriented strategy that optimizes local revenues by focusing on the analysis of internal strengths and weaknesses of tourism sites.

Optimal management and maximizing tourism promotion is one of indicators of an increased local revenue, thus the central and local governments have an archipelago development strategy particularly an ideal beach tourism object and considers priority scale that has been adjusted to the sites.

\section{REFERENCES}

[1] BPS Indonesia, 1995 - 2015. .Macroeconomic Report Annually. Magazine on Indonesia Statiscal Datas, Vol. 4, No. 4

[2] Meihami, Bahram dan Karami, Jasim. 2014. Review Some Effects of the Investment in the Tourism Sector (Evidence of the Qhorveh City. International Letters of Natural Sciences Vol. 25 (2014) pp 39-46

[3] Penidit. 2011. The Impact of Trade Liberalization and Increased Tourism Demand on Macro and Sectoral Economic Performance in Indonesia. Thesis of Bogor Agricultural University (IPB). Bogor

[4] Santi, F., Oktarina, Budiman dan Kustiari. 2013. Tourism Investment, Supply and Demand in Indonesia : Impact and Factor Analysis. The First International Conference on Law, Business and Government 2013. UBI, Indonesia. 